\title{
Influence of Selected Variables on Mathematics Teaching and Learning in Ilorin South Local Government, Kwara State
}

\author{
Ayodeji John Enikanolaye \\ Department of Science Education, Faculty of Education, University of Ilorin, Ilorin, Nigeria, \\ enikanolayeayodeji@gmail.com \\ Morenikeji Alex Akanmu \\ Department of Science Education, Faculty of Education, University of Ilorin, Ilorin, Nigeria, \\ alexakanmu@gmail.com
}

\begin{abstract}
Effective teaching and learning and academic performance is affected by several factors which includes parent social economic status, school facilities, motivation, students' attitude towards mathematics. The study was a descriptive study of survey type and supported qualitatively. Questionnaire and interview were employed for data collection. The target population for this study comprised of all the three thousand four hundred and sixty $(3,460)$ senior secondary school II (SS 2) mathematics students and their teachers in Ilorin South, Kwara State (Kwara State Universal Basic Education, 2019). Multi- stage sampling technique was used for the sampling process. In the first stage, four (4) wards in Ilorin south Local Government Area were selected randomly through balloting method namely: Akanbi ward III; Akanbi ward IV; Akanbi ward V and Okaka ward I. In the second stage, balloting method was used to select two (2) schools each from the four (4) wards making a total of eight (8) schools. In the third stage, twenty percent $(20 \%)$ of the students in each of these schools were selected through systematic random sampling technique. The questionnaires were filled by three hundred and forty-six (346) students and ten (10) mathematics teachers making a total of 356 respondents. Furthermore, out of the 356 respondents eight (8) students and ten (10) mathematics teachers were interviewed. Demographic data of respondents were analysed using frequency counts and percentages while the research questions were also descriptively answered using frequency and percentage. The study revealed that: (i) teacher's qualification have an influence on effective teaching and learning of mathematics in schools (ii) teacher's experience does not have influence on effective teaching and learning of Mathematics in schools (iii) availability and use of instructional material influence effective teaching and learning of Mathematics in secondary schools (iv) school facilities and equipment and other teaching material was also found to have influence on effective teaching and learning of mathematics in secondary schools (v) Teachers' teaching experiences is the most influential factor affecting effective teaching and learning of mathematics.
\end{abstract}

Keywords: variables, instructional materials, school facilities, teacher's qualification, mathematics

\section{INTRODUCTION}

Mathematics is one of the core subjects at both junior and senior secondary school levels in Nigeria. This is due to its relevance to our daily life. Mathematics has different definitions as different scholars define it based on their own understanding. Mathematics is an abstract of number, quantity and space (Charles-Organ, 2014). According to Charles-Organ (2014) mathematics is viewed as a science that draws necessary conclusions. The researcher further stated that Mathematics is a language used to

Citation: Enikanolaye, A. J., \& Akanmu, M. A. (2020). Influence of Selected Variables on Mathematics Teaching and Learning in Ilorin South Local Government, Kwara State. Anatolian Journal of Education, 5(1), 67-78. https://doi.org/10.29333/aje.2020.517a 
portray problems arising in all branches of sciences and technology because of its relationship with other school subjects. Also, Salman and Adeniyi (2012) observed that the importance of mathematics to industries and technologies cannot be under estimated. Salman (2002) stated that mathematics is useful in area of business administration, banking and finance, accounting and sociology. Mathematics serves as a nerve and guiding knowledge for science and technology. This is to emphasize that without mathematics, there is no science and without science there is no technology (Salman and Adeniyi 2012). Nation that plan to become scientifically and technologically developed cannot do without the acquisition of the requisite mathematics knowledge; such nation must have in her barn the procedure and consumers of mathematical knowledge (Okeke, 2009).

Despite the importance and usefulness of mathematics to the society, the performance of students in mathematics is not encourage enough (Uche, 2011). Several factors, such as class size, teacher competency, school facilities, student's attitudes towards mathematics, and lack of motivation are responsible for the poor performance in mathematics (Zachariah, Komen, George \& George, 2012). The issue of poor academic performance of students in Nigeria has been of much concern to the government, parents, teachers and even the students themselves. The quality of education not only depends on the teachers as reflected in the performance of their duties, but also, in the effective coordination of the school variables (Amoo \& Onasanya, 2010).

Effective teaching and learning of mathematics is undoubtedly the most crucial objective in school (seah, 2007). According to Rivkin, Hanusahek and kain (2005) econometric analysis suggested that some teachers are more effective than others, and these differences in their effectiveness have an effect on students' academic performance. Effectiveness of a teacher is the degree at which teachers achieves desired effects upon students (Stanford, 2001). Teachers are one of the important resource that a school should have to achieve better results. Teacher's qualification and working experience have been recognize widely by researchers and policy maker to be the most powerful school related influence on students achievement in academic (Motoko, Gerald, LeTendre \& Scribner, 2007). Kosgei, kirwa, Odhiambo and Ayugi (2013) conducted a study to affirm the relationship between teachers' quality and students' achievements. The findings shows that teacher's working experience has significant influence on students' achievement and also ascertain that teachers' qualification has no influence on students' achievement. Wenglinsky (2000) examined teachers working experience on student academic achievement in both science and mathematics. The research found out that teachers working experience have an influence on student performance both in science and mathematics. Abe (2014) conducted a study on effect of teachers' qualification on student achievement in mathematics. It was revealed that there was a significant difference between the performance of student taught by teacher wiith high qualification and student taught by teacher with low qualification. The difference was in favour of student taught by teacher with high qualification. Goldhaber and Brewer (2000) revealed that there was a positive relationship between teachers qualification and student academic performance in mathematics. Hanushek (1990) examined the impact of teacher's qualification on student academic achievement. Findings revealed that there is no positive correlation between students' performance and teacher's qualification. Also, Asikhia (2010) investigated students and teachers perception of the cause of poor academic performance in Ogun State secondary school, Nigeria. The result showed that teachers' qualification and Students environment do not influence students' performance.

One of the factors associated with effective teaching and learning is school facilities. School facilities are contrivance used for the benefit of education. These facilities include electricity, chairs, tables, laboratory equipment, audio-visual aids, workshops, library, staff room and playground which school has (Alimi, 2004). When school facilities are fully available and utilized, they influence effective teaching and learning. Adesola (2005) revealed that availability of school facilities is indeed a great addition to the teacher and it goes a long way to show the ability to solve difficult problem and

Anatolian Journal of Education, April $2020 \bullet$ Vol.5, No.1 
commitment of teachers towards effective teaching delivery of lesson. Research findings on the influence of school facilities on effective teaching and learning shows that school facilities influence student academic performance in the school system (Akinfolarin, 2008; Ayodele, 2000; Vandiver, 2011). Similarly, Cynthia and Megan (2008) on influence of school facilities on academic performance, the study revealed that there exist a relationship between quality of school facility and student achievement both in Mathematics and English.

Omo (2011), stated that the role teacher play on students' academic achievement are undisputed. Instructional objectives cannot be achieved by teacher without the desire change in students' behaviour. Therefore, teacher is expected to use instructional material for effective teaching and learning. Isola (2010) defined instructional materials as devices or objects that aids the presentation of lesson in a logical and sequential to students. Instructional materials serves as a guide or support to the effective teaching and learning (Abiodun-Oyebanji\&Adu, 2007). Instructional material therefore, is an instrument that teachers or students uses to fast-track effective teaching and learning. Instructional materials facilitate learning by sustaining attention, offer opportunity for independent and individualized learning and stimulating students' interest (NTI Manual, 2006). Adeluku (2012) conducted a study on the influence of instructional materials in teaching and learning of mathematics in senior secondary school in Cross River State. Findings showed that students taught using instructional materials perform better than students taught without instructional materials.

Against the foregoing, it would therefore be very necessary for mathematics teachers, secondary school administrators and the government to take a critical look at the ways of improving the status of mathematics as a subject in secondary school. This research paper examined the influence of some variables affecting effective teaching and learning of mathematics in secondary schools and proffer far reaching solutions to these problems.

\section{Statement of the Problem}

The quality of mathematics teaching and learning has been a major challenges and concerns of researchers. This is evidence in the performance of students in mathematics (chief Examiner Report, 2010-2016). Several factors have been identified by researchers for the poor performance of students in mathematics. These factors are inadequate mathematics teachers, class size, teacher competency, school facilities, student's attitudes towards mathematics, and lack of motivation (Iwuoha, 2007; Tuncay \& Omur, 2009; Zachariah, Komen, George \& George, 2012).

Much as the situation described here causes concern, it is not yet known why some students fail to attain the standards expected of them. Therefore, it is pertinent to investigate the problems facing teaching and learning of mathematics at senior secondary schools in Ilorin South Local Government Area of Kwara State. The researcher would therefore like to establish the influence of variables such as school facilities, teachers' qualification, teaching experience and availability of instructional materials' on student academic performance in mathematics.

\section{Purpose of the Study}

The main purpose of this research is to explore the influence of some variables in teaching and learning of Mathematics in selected Secondary School in Ilorin South Local Government area of Kwara State. Specifically, the study sought to;

i. find out the influence of mathematics teacher's qualification on teaching and learning of mathematics in senior secondary school.

ii. examine the influence of mathematics teacher's teaching experience on teaching and learning mathematics in senior secondary school. 
iii. determine the influence of instructional materials on teaching and learning of mathematics in senior secondary school.

iv. investigate the influence of school facilities on teaching and learning of mathematics in senior secondary school.

v. find out which factors is most influential factor in teaching and learning of mathematics

\section{Research Questions}

The following questions guided this study

1. To what extent does mathematics teacher's qualification influence teaching and learning of mathematics in senior secondary school?

2. To what extent does mathematics teacher's teaching experience influence teaching and learning of mathematics in senior secondary school?

3. To what extent does instructional materials influence teaching and learning of mathematics in senior secondary school?

4. To what extent does school facilities influence teaching and learning of mathematics in senior secondary school?

5. which factors is most influential factor in teaching and learning of mathematics?

\section{METHOD}

The research is a descriptive study of survey type and it is supported quantitatively. Questionnaire and interview were employed for data collection. The use of questionnaire and interview are considered appropriate to get the information on influence of selected variables on effective teaching and learning of mathematics. The target population for this study comprised of all the three thousand four hundred and sixty $(3,460)$ senior secondary school II (SS 2) mathematics students and their teachers in Ilorin South, Kwara State (Kwara State Universal Basic Education, 2019). Multi- stage sampling technique was used for the sampling process. In the first stage, four (4) wards in Ilorin south Local Government Area were selected randomly through balloting method namely: Akanbi ward III; Akanbi ward IV; Akanbi ward V and Okaka ward I. In the sec ond stage, balloting method was used to select two (2) schools each from the four (4) wards making a total of eight (8) schools. In the third stage, twenty percent $(20 \%)$ of the students in each of these schools were selected through systematic random sampling technique. A total of three hundred and forty-six (346) students and ten (10) mathematics teachers were involved in the study which is equivalent to ten percent (10) of the whole population.

Furthermore, Eight (8) students (one from each selected schools) and ten (10) mathematics teachers that were on ground were interviewed. The research instrument used for this study was a wellstructured questionnaire entitled influence of selected variables on effective teaching and learning of mathematics survey (PETLFAS). The questionnaire was validated by three experts in the field of mathematics education. The reliability of the instrument was established through the use of split-half method. The correlation analysis data generated was done using Spearman Ranking Order co-efficient. The reliability co-efficient of $0.69 \mathrm{r}$ was obtained. The instrument consisted of two sections (A \& B); "A" contains demographic information of the respondents (Mathematics teachers and students) while section "B" contains structured question items raised from the research questions rated using 4 likert scale of Strongly Agree (SA), Agree (A), Disagree (D), and Strongly Disagree.

The researcher and two research assistants administered the questionnaire on the sample respondents. The researcher researcher personally interviewed the eight (8) students and the ten (10) mathematics teachers. A letter expressing the motive of the research work was introduced before the administration and thorough permission was sought from the administrators, thereafter, the instrument was administered and collected back upon completion. The data collected through the administered questionnaire were subjected to both descriptive statistics. Demographic data of respondents were 
analysed using frequency counts and percentages, the research questions were descriptively answered using mean and standard deviation.

\section{FINDINGS}

Results of demographic data collected are presented in tables 1, 2, 3 with relevant discussions:

Table 1

Distribution of Respondents on the basis of Gender

\begin{tabular}{lcc}
\hline Gender & Frequency (No) & Percentage $(\%)$ \\
\hline Student & & \\
Male & 206 & 59.54 \\
Female & 140 & 40.46 \\
Total & 346 & \\
Teacher & & 70.00 \\
Male & 07 & 30.00 \\
Female & 03 & \\
Total & 10 & \\
\hline
\end{tabular}

Table 1 show that $206(59.54 \%)$ of the respondents were male students while $140(40.46 \%)$ were the female students. Also, 7 representing $70.0 \%$ of the teachers were male mathematics teachers while the remaining $3(30.0 \%)$ were the female mathematics teachers sampled.

Table 2

Distribution of Respondents on the basis of Teachers' Qualification

\begin{tabular}{lcl}
\hline Qualification & Frequency $(\mathrm{No})$ & Percentage $(\%)$ \\
\hline B.ED/B.SC & 5 & 50.0 \\
HND/PGDE & 2 & 20.0 \\
NCE & 1 & 10.0 \\
MSc/M.Ed. & 2 & 20.0 \\
Total & 10 & 100 \\
\hline
\end{tabular}

Table 2 revealed that the highest qualification of the teachers sampled is $\mathrm{B}$. Ed/Sc. with 5 representing $50.0 \%$ of the teachers while 2 representing $20.0 \%$ have HND/PGDE, $1(10.0 \%)$ had NCE while the remaining $2(20.0 \%)$ had M.Sc./M.Ed.

Table 3

Distribution of Respondents on the basis of Teachers' Working Experience.

\begin{tabular}{lcl}
\hline Working Experience & Frequency (No) & Percentage $(\%)$ \\
\hline $0-5$ years & 4 & 40.0 \\
$6-10$ years & 4 & 40.0 \\
$11-15$ years & 2 & 20.0 \\
Total & 10 & 100 \\
\hline
\end{tabular}

Table 3 shows that 4 teachers representing $40.0 \%$ have spent 0 -5years in service, 4 representing $40.0 \%$ of the teachers had 6-10years experience and 2 (20.0\%) had 11-15years teaching experience.

\section{Analysis of Research Questions}

This section descriptively answer the research raised for the study through the use of frequency and percentage.

Research Question 1: To what extent does teacher's qualification influence teaching and learning of mathematics in senior secondary school? 
Table 4

Frequency and Percentages Showing the Extent of Teacher's Qualification Influence on Effective Teaching and Learning of Mathematics $(\mathrm{N}=356)$

\begin{tabular}{|c|c|c|c|c|}
\hline $\mathrm{S} / \mathrm{N}$ & $\begin{array}{l}\text { Influence of Teacher's qualification on teaching and learning of } \\
\text { Mathematics }\end{array}$ & $\begin{array}{l}\text { Agree } \\
(\%)\end{array}$ & $\begin{array}{l}\text { Disagree } \\
(\%)\end{array}$ & $\begin{array}{l}\text { Undecided } \\
(\%)\end{array}$ \\
\hline 6. & $\begin{array}{l}\text { Unqualified teachers have an adverse effect on the teaching and } \\
\text { learning of Mathematics in secondary school. }\end{array}$ & $\begin{array}{c}299 \\
(83.99)\end{array}$ & $\begin{array}{c}50 \\
(14.04)\end{array}$ & $\begin{array}{c}7 \\
(1.97)\end{array}$ \\
\hline 7. & $\begin{array}{l}\text { Teachers' academic qualification determines students' academic } \\
\text { performance in mathematics }\end{array}$ & $\begin{array}{c}300 \\
(84.27)\end{array}$ & $\begin{array}{c}51 \\
(14.33)\end{array}$ & $\begin{array}{c}5 \\
(1.40)\end{array}$ \\
\hline 8. & $\begin{array}{l}\text { Teachers' educational qualification determine his/her } \\
\text { instructional strategies }\end{array}$ & $\begin{array}{c}289 \\
(81.18)\end{array}$ & $\begin{array}{c}60 \\
(16.85)\end{array}$ & $\begin{array}{c}7 \\
(1.97)\end{array}$ \\
\hline 9. & $\begin{array}{l}\text { Educational background of teachers influence his/her teaching } \\
\text { methodology }\end{array}$ & $\begin{array}{l}278 \\
(78.09)\end{array}$ & $\begin{array}{c}73 \\
(20.51)\end{array}$ & $\begin{array}{c}5 \\
(1.40)\end{array}$ \\
\hline 10. & $\begin{array}{l}\text { Educational attainment of Mathematics teachers influences their } \\
\text { teaching abilities and skills. } \\
\text { Average }\end{array}$ & $\begin{array}{l}312 \\
(87.64) \\
296 \\
(83.14)\end{array}$ & $\begin{array}{c}38 \\
(10.67) \\
54 \\
(15.17)\end{array}$ & $\begin{array}{c}6 \\
(1.69) \\
6 \\
(1.69)\end{array}$ \\
\hline
\end{tabular}

Table 5

Frequency and Percentage Showing Response from the Interviewer on the Influence of Teacher's Qualification on Teaching and Learning of Mathematics

\begin{tabular}{lcc}
\hline Question & \multicolumn{2}{c}{ Frequency } \\
\cline { 2 - 3 } & Yes $(\%)$ & No (\%) \\
\hline Does teacher's qualification influence the & 15 & 3 \\
teaching and learning of mathematics & $(83.33)$ & $(16.67)$ \\
\hline
\end{tabular}

In table 4, two hundred and ninety six (296) respondents representing $83.14 \%$ agreed that teacher's qualification influence teaching and learning of mathematics, fifty-four (54) respondents representing $15.17 \%$ disagree while six (6) respondents representing $1.69 \%$ were undecided. This indicated that to a great extent, respondents' perceives teacher's qualification to influence the quality of Mathematics teaching and learning in secondary school. Also, in table 5, fifteen (15) of the interviewer were of the opinion that teachers qualification influence teaching and learning of mathematics while the remaining three (3) were of the opinion that teacher's qualification doesn't have any influence on teaching and learning of mathematics.

Research Question 2: To what extent does teaching experience influence teaching and learning mathematics in senior secondary school?

Table 6

Frequency and Percentage Showing the Extent of Teacher's Experience Influence on Effective Teaching and Learning of Mathematics $(\mathrm{N}=356)$

\begin{tabular}{|c|c|c|c|c|}
\hline $\mathrm{S} / \mathrm{N}$ & $\begin{array}{l}\text { Influence of Teacher's Experience on teaching and learning of } \\
\text { Mathematics }\end{array}$ & $\begin{array}{l}\text { Agree } \\
(\%)\end{array}$ & $\begin{array}{l}\text { Disagree } \\
(\%)\end{array}$ & $\begin{array}{c}\text { Undecided } \\
(\%)\end{array}$ \\
\hline 11 & $\begin{array}{l}\text { Most Mathematics teachers have adequate knowledge of the } \\
\text { subject matter. }\end{array}$ & $\begin{array}{c}200 \\
(56.18)\end{array}$ & $\begin{array}{l}106 \\
(29.78)\end{array}$ & $\begin{array}{l}50 \\
(14.04)\end{array}$ \\
\hline 12 & $\begin{array}{l}\text { Lack of adequate knowledge on the subject matter influence the } \\
\text { quality of mathematics teaching in secondary school. }\end{array}$ & $\begin{array}{c}50 \\
(14.04)\end{array}$ & $\begin{array}{l}300 \\
(84.27)\end{array}$ & $\begin{array}{c}6 \\
(1.69)\end{array}$ \\
\hline 13 & $\begin{array}{l}\text { Most inexperience teachers find it difficult to adapt to structural } \\
\text { changes in teaching of mathematics }\end{array}$ & $\begin{array}{c}46 \\
(12.92)\end{array}$ & $\begin{array}{c}310 \\
(87.08)\end{array}$ & $\begin{array}{c}0 \\
(0)\end{array}$ \\
\hline 14 & $\begin{array}{l}\text { Teachers teaching experience determines their emotional } \\
\text { stability }\end{array}$ & $\begin{array}{c}36 \\
(10.11)\end{array}$ & $\begin{array}{c}320 \\
(89.89)\end{array}$ & $\begin{array}{l}0 \\
(0)\end{array}$ \\
\hline 15 & $\begin{array}{l}\text { Lack of enough teaching experience has adverse effect on the } \\
\text { teachers' performance. } \\
\text { Average }\end{array}$ & $\begin{array}{c}175 \\
(49.16) \\
102 \\
(28.65)\end{array}$ & $\begin{array}{l}181 \\
(50.84) \\
243 \\
(68.26)\end{array}$ & $\begin{array}{c}0 \\
(0) \\
11 \\
(3.09)\end{array}$ \\
\hline
\end{tabular}


Table 7

Frequency and Percentage Showing Response from the Interviewer on the Influence of Teacher's Teaching Experience on Teaching and Learning of Mathematics

\begin{tabular}{lcc}
\hline Question & \multicolumn{2}{c}{ Frequency } \\
\cline { 2 - 3 } & Yes (\%) & No (\%) \\
\hline Does mathematics teacher's teaching experience & 7 & 11 \\
influence the teaching and learning of mathematics & $(38.89)$ & $(61.11)$ \\
\hline
\end{tabular}

In table 6, one hundred and two (102) respondents representing $28.65 \%$ agreed that mathematics teacher's teaching experience influence teaching and learning of mathematics, two hundred and fortythree (243) respondents representing 68.26\% disagree while eleven (11) respondents representing $3.09 \%$ were undecided. This indicates that teacher's teaching experience does not influence teaching and learning of mathematics in secondary school. The interview result in table 7 also, indicated that mathematics teacher's teaching experience do not influence mathematics teaching and learning. Seven (7) of the interviewers were of the opinion that teacher's teaching experience influence teaching and learning of mathematics while eleven (11) were of the opinion that teaching experience doesn't influence teaching and learning of mathematics.

Research Question 3: To what extent does instructional materials influence teaching and learning of mathematics in senior secondary school?

Table 8

Frequency and Percentage Showing the Extent of Instructional Materials Influence on Effective Teaching and Learning of Mathematics ( $\mathrm{N}=356)$

\begin{tabular}{|c|c|c|c|c|}
\hline $\mathrm{S} / \mathrm{N}$ & $\begin{array}{l}\text { Influence of Instructional materials on teaching and learning of } \\
\text { Mathematics }\end{array}$ & $\begin{array}{c}\text { Agree } \\
(\%)\end{array}$ & $\begin{array}{l}\text { Disagree } \\
(\%)\end{array}$ & $\begin{array}{l}\text { Undecided } \\
(\%)\end{array}$ \\
\hline 16 & $\begin{array}{l}\text { Teachers' perception of the teaching profession could influence the } \\
\text { quality of teaching. }\end{array}$ & $\begin{array}{c}251 \\
(70.51)\end{array}$ & $\begin{array}{l}101 \\
(28.37)\end{array}$ & $\begin{array}{l}4 \\
(1.12)\end{array}$ \\
\hline 17 & Instructional materials determines the quality of teaching and learning & $\begin{array}{l}280 \\
(78.65)\end{array}$ & $\begin{array}{l}76 \\
(21.35)\end{array}$ & $\begin{array}{l}0 \\
(0)\end{array}$ \\
\hline 18 & $\begin{array}{l}\text { Lack of instructional materials affects the overall objectives of } \\
\text { effective teaching and learning }\end{array}$ & $\begin{array}{l}270 \\
(75.84)\end{array}$ & $\begin{array}{l}70 \\
(19.66)\end{array}$ & $\begin{array}{l}16 \\
(4.49)\end{array}$ \\
\hline 19 & $\begin{array}{l}\text { The use of instructional materials enhance effective teaching and } \\
\text { learning of Mathematics }\end{array}$ & $\begin{array}{l}303 \\
(85.11)\end{array}$ & $\begin{array}{c}53 \\
(14.89)\end{array}$ & $\begin{array}{c}0 \\
(0)\end{array}$ \\
\hline 20 & $\begin{array}{l}\text { Inadequate or obsolete instructional materials influence students } \\
\text { learning potentials negatively } \\
\text { Average }\end{array}$ & $\begin{array}{c}301 \\
(84.55) \\
281 \\
(78.93)\end{array}$ & $\begin{array}{c}55 \\
(15.45) \\
71 \\
(19.94)\end{array}$ & $\begin{array}{l}0 \\
(0) \\
4 \\
(1.12)\end{array}$ \\
\hline
\end{tabular}

Table 9

Frequency and Percentage Showing Response from the Interviewer on the Influence Instructional Material on Teaching and Learning of Mathematics

\begin{tabular}{lcc}
\hline Question & \multicolumn{2}{c}{ Frequency } \\
\cline { 2 - 3 } & Yes $(\%)$ & No (\%) \\
\hline Does mathematics teacher's teaching experience influence & 12 & 6 \\
the teaching and learning of mathematics & $(66.67)$ & $(33.33)$ \\
\hline
\end{tabular}

In table 8, two hundred and eighty-one (281) respondents representing $78.93 \%$ agreed that instructional material influence teaching and learning of mathematics, seventy-one (71) respondents representing $19.94 \%$ disagree while four (4) respondents representing $1.12 \%$ were undecided. This indicates that to a great extent, the use of instructional material influence teaching and learning of mathematics in secondary school. The interview result in table 9 also indicated that use of instructional material influence mathematics teaching and learning. Twelve (12) of the interviewers were of the opinion that use of instructional material influence mathematics teaching and learning while six (6) 
were of the opinion that use of instructional material doesn't influence mathematics teaching and learning.

Research Question 4: To what extent does school facilities influence teaching and learning of mathematics in senior secondary school?

Table 10

Frequency and Percentage Showing the Extent of School Facilities Influence on Effective Teaching and Learning of Mathematics ( $\mathrm{N}=356)$

\begin{tabular}{|c|c|c|c|c|}
\hline $\mathrm{S} / \mathrm{N}$ & Influence of School facilities on teaching and learning of Mathematics & $\begin{array}{l}\text { Agree } \\
(\%)\end{array}$ & $\begin{array}{l}\text { Disagree } \\
(\%)\end{array}$ & $\begin{array}{l}\text { Undecided } \\
(\%)\end{array}$ \\
\hline 21 & $\begin{array}{l}\text { Lack of basic amenities e.g electricity resources room furniture etc. makes } \\
\text { the use of teaching aids difficult or impossible for teacher. }\end{array}$ & $\begin{array}{c}234 \\
(65.73)\end{array}$ & $\begin{array}{c}120 \\
(33.71)\end{array}$ & $\begin{array}{c}2 \\
(0.56)\end{array}$ \\
\hline 22 & $\begin{array}{l}\text { Poor status of school infrastructural facilities influence effective teaching } \\
\text { and learning }\end{array}$ & $\begin{array}{c}303 \\
(85.11)\end{array}$ & $\begin{array}{l}49 \\
(13.76)\end{array}$ & $\begin{array}{c}4 \\
(1.12)\end{array}$ \\
\hline 23 & $\begin{array}{l}\text { Inadequate library facilities influence effective teaching and learning of } \\
\text { Mathematics }\end{array}$ & $\begin{array}{l}291 \\
(81.74)\end{array}$ & $\begin{array}{l}61 \\
(17.14)\end{array}$ & $\begin{array}{c}4 \\
(1.12)\end{array}$ \\
\hline 24 & $\begin{array}{l}\text { Overcrowded classroom affect the quality of teaching and learning of } \\
\text { Mathematics }\end{array}$ & $\begin{array}{c}260 \\
(73.03)\end{array}$ & $\begin{array}{l}95 \\
(26.69)\end{array}$ & $\begin{array}{c}1 \\
(0.28)\end{array}$ \\
\hline 25 & $\begin{array}{l}\text { Poor development of internet facilities and computer gadgets affects } \\
\text { teaching and learning of Mathematics }\end{array}$ & $\begin{array}{c}299 \\
(83.99) \\
277 \\
(77.81)\end{array}$ & $\begin{array}{c}50 \\
(14.04) \\
75 \\
(21.07)\end{array}$ & $\begin{array}{c}7 \\
(1.97) \\
4 \\
(1.12)\end{array}$ \\
\hline
\end{tabular}

Table 11

Frequency and Percentage Showing Response from the Interviewer on the Influence of School Facilities on Teaching and Learning of Mathematics

\begin{tabular}{ccc}
\hline \multicolumn{1}{c}{ Question } & \multicolumn{2}{c}{ Frequency } \\
\cline { 2 - 3 } & Yes (\%) & No (\%) \\
\hline $\begin{array}{l}\text { Does mathematics teacher's teaching experience influence the } \\
\text { teaching and learning of mathematics }\end{array}$ & 13 & 5 \\
\end{tabular}

In table 10, two hundred and seventy-seven (277) respondents representing $77.81 \%$ agreed that school facilities influence teaching and learning of mathematics, seventy-five (75) respondents representing $21.07 \%$ disagree while four (4) respondents representing $1.12 \%$ were undecided. This indicates that to a great extent, school facilities influence teaching and learning of mathematics in secondary school. The interview in table 11 also indicated that school facilities influence teaching and learning of Mathematics. Thirteen (13) of the interviewers were of the opinion that school facilities influence mathematics teaching and learning while five (5) were of the opinion that school facilities doesn't influence mathematics teaching and learning.

Research Question 5: Which factor is most influential factor in teaching and learning of mathematics?

Table 12

The most influential factor in teaching and learning of mathematics

\begin{tabular}{ll}
\hline Factors & Frequency $(\%)$ \\
\hline Teacher's qualification & $32(8.99)$ \\
Teaching experience & $201(56.46)$ \\
Instructional materials & $101(28.37)$ \\
School facilities & $22(6.18)$ \\
\hline
\end{tabular}




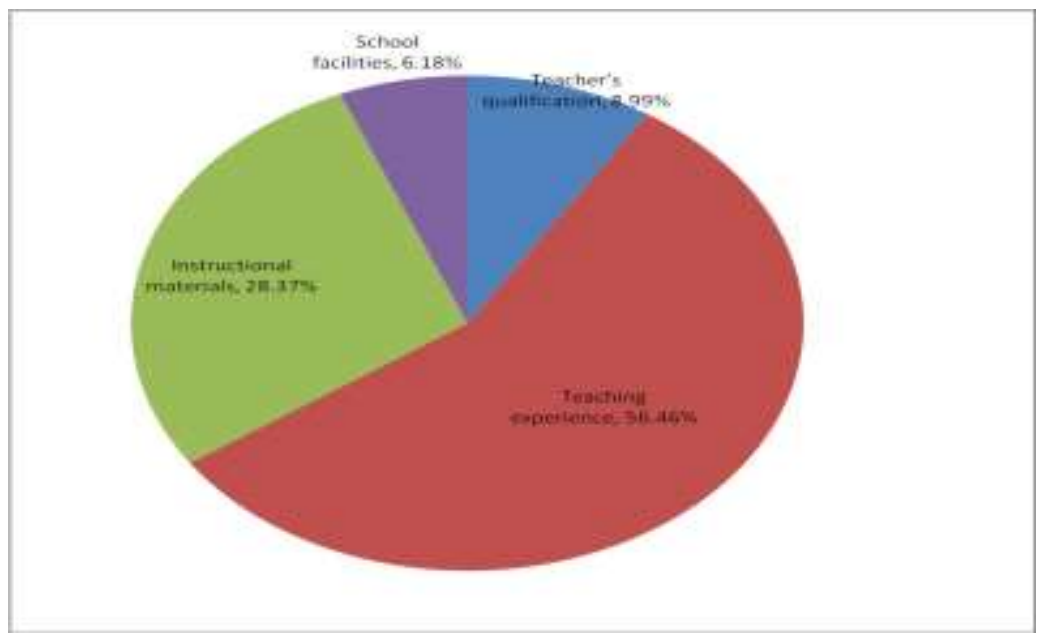

Figure 1

General Response on most influential factor in teaching and learning of mathematics

The majority of the correspondents as shown in table 12 and figure 1 revealed that teachers' teaching experience is the most influential factor affecting effective teaching and learning of mathematics with $201(56.46 \%)$ respondents followed by instructional material with $101(28.37 \%)$ respondents, Teacher qualification with $32(8.99 \%)$ respondents and School facilities with 22 (6.18\%) respondents.

\section{DISCUSSION}

The chapter present the analysis of data collected from the administered questionnaire and the discussion of findings were presented here in line with the related literatures;

The results as indicated in table 4, 8 and10 with interview conducted indicated that respondents perceived influence of teacher's qualification, use of instructional materials and availability of school facilities and equipment significantly influence teaching and learning of Mathematics in secondary schools.

The findings concur that teacher's qualification have an influence on teaching and learning of mathematics in secondary schools. This agrees with the view of Abe (2014), Wenglinsky (2000) and Goldhaber and Brewer (2000) who conducted a study on effect of teachers' qualification on student achievement in mathematics. The findings revealed that there was a significant difference between the performance of student taught by teacher wiith high qualification and student taught by teacher with low qualification. Asikhia (2010) however disagree, saying that teachers' qualification and Students environment do not influence students' performance

Also, the findings revealed that teacher's experience does not have significance influence on teaching and learning of Mathematics in secondary schools. This agrees with the view Hanushek (1990). This finding however disagree with view Kosgei, kirwa, Odhiambo and Ayugi (2013) who perceived teacher's experience an important component in classroom interaction which enhance the quality of instruction and the rate at which instructional messages could be passing across to different categories of learners.

Availability of instructional material influence teaching and learning of Mathematics in secondary schools. The finding agreed with the views of Adeluku (2012) who perceived instructional material to have an influence on teacher's quality of teaching and learning in secondary schools. 
Similarly, school facilities and equipment and other teaching material were also found to have influence on teaching and learning in secondary school. This agrees with the view of Ayodele (2000), Vandiver (2011), Akinfolarin (2008) and Cynthia and Megan (2008) that perceives quality of inputs to guarantee quality output in educational system.

Finally teachers' teaching experience is most influential factor among all the factors selected which affect effective teaching and learning of mathematics

\section{CONCLUSION}

Based on the findings from the analyzed data the researcher concludes that;

1. Teachers' qualification has an influence on teaching and learning of mathematics in secondary schools;

2. Teachers' teaching experience has no influence on teaching and learning of mathematics in secondary schools;

3. Insufficient or inadequate of instructional materials contribute significantly to the problems facing teaching and learning of mathematics in secondary;

4. School facilities have an influence on teaching and learning of mathematics in secondary schools; and

5. Teachers' teaching experience is the most influential factor affecting the teaching and learning of mathematics from the factors selected in the study.

\section{Recommendations}

Based on the findings and conclusions drawn, the following recommendations were made;

1. More emphasis should be placed on teacher's qualification as pre-requisite for teaching profession and only certified professional teachers with teaching qualification should be employed to teach mathematics at senior secondary school classes.

2. Government should organize periodic seminars, conferences and workshops to further update teachers on the current teaching methodology and strategies to boost student performance.

3. Government should provide appropriate Instructional materials and facilities to support effective teaching and learning in secondary schools. Also, there is need for maintenance culture on the existing instructional facilities in the schools.

4. Facilities in schools should be properly evaluated and where necessary upgrade to facilitate conducive teaching and learning. The condition of classroom, library facilities and offices should be improved on.

5. Teachers' teaching experience should be given adequate consideration in teaching and learning of mathematics.

\section{Suggestions for further Studies}

It is suggested that similar research work be carried out in other Local Government Area of the State owing to the limitations and scope of the present study.

It is also suggested that researches can be carried out on the following topics:

1. An investigation into the effect of teacher's qualifications on effective teaching and learning of Mathematics in selected secondary schools in Ilorin West Local Government Area of Kwara State.

Influence of peer group on students' academic performance in Mathematics in selected secondary schools in Ilorin metropolis 


\section{REFERENCES}

Abe, O. (2014). The effects of teachers' qualification on Students' Performance in mathematics. Sky Journal of Education Research, 2(1), 10-14.

Abiodun-Oyebanji, O., \& Adu, E. T. (2007). Principals' performance in instructional supervision in the use of resources in senior secondary schools in Ekiti. Journal of Education Focus, 1(1), 8-14.

Adeluku, S. A. (2012). The influence of instructional materials on academic performance of senior secondary school students in Mathematics in Cross River State. Global Journal of Educational Research and Review, 2(7), 165-177.

Adesola, A. A. (2005). Resource provision and utilization, mathematics ability and learning environment as prediction of learning outcome in undergraduate practical Geography (Unpublished doctoral dissertation). University of Ibadan, Ibadan.

Akinfolarin, C. A. (2008). Resource utilization in vocational and technical education in College of Education in South-West Nigeria (Unpublished doctoral dissertation). University of Ado-Ekiti.

Alimi, O. S. (2004). Appraisal of the adequacy of availability school plant for primary education in Ayedaade Local Government Area of Osun State. Educational Thought 4(1)64-69.

Amoo, S. A., \& Onasanya, W. A. (2010). Maintaining a gender-free culture in mathematics classroom practices in junior secondary schools for the attainment of millennium development goals. Abacus: The Journal of mathematical Association of Nigeria, 33(1), 70-79.

Asikhia, O. A. (2010) Students' and teachers' perceptions of the causes of academic performance in Ogun State secondary schools, Nigeria. European Journal of Social Sciences, 13(2).

Ayodele, J. B. (2000). School size, class size and teacher quality as correlation of internal efficiency in primary school in Ondo State, Nigeria (Unpublished doctoral dissertation). University of Ibadan.

Charles-Organ, G. (2014). Metacognitive strategy and Senior Secondary School Mathematics Students' Misconceptions in River State,Nigeria. J of Math Association of Nigeria, 39 (1), 234-246.

Cynthia, U., \& Megan, T. (2008). The walls speak: the interplay of quality facilities, school climate and student achievement. Journal of Educational Administration, 46(1), 55-73.

Federal Republic of Nigeria (2013). National Policy on Education. Lagos, Nigeria: NERDC.

Gladys, C. O. (2015). Mathematics as tool for achieving the vision 20:2020 Goal of National Transformation. International Journal of Education, Learning and Development, 8(3), 57-61.

Goldhaber, D. D., \& Brewer, D. J. (2000). Does teacher certification matter? High school teacher certification status and student achievement. Education and Policy Analysis, 22, 129-45.

Hanushek, E. (1990). The impact of differential expenditure on school performance. Educational Research, 14(4), 20-25.

Isola, O. M. (2010). Effect of standardized and improvised instructional materials on students' academic achievement in secondary school physics (Unpublished master thesis). University of Ibadan.

Iwuoha, R. K. (2001). Factors affecting scholarstic achievement: an experimental study of some factors related to scholarstics achievement. Journal of Education, 13(4), 28-33.

Kosgei, A., Kirwa, M., Odhiambo, O., \& Ayugi, M. (2013). Influence of teacher characteristics on Students academic achievement among secondary schools. J. of Education and Practice, 4(3), 76-82. 
Larson, M. (2002). Essential characteristics of effective Mathematics instruction. Houghton Mufflin.

National Center for Education Standards (2000). NAEP 1996: Trends in academic progress. Washington D.C.: US department of education.

National Teachers' Institute (2006). Manual for the retraining of primary school teachers. MDG project Kaduna.

Motoko, A., Le Tendre, K., \& Scribner, J. (2007). Teacher quality, opportunity gap, and national achievement in 46 countries. Educational Researcher, 36(7), 369-387.

Okeke, M. (2009). Gender and gap access to secondary school science education: The way forward. WAEC Monthly Seminar Paper, 2: 103-113.

Omo, A. (2011). Quality of teachers and performance: Evidence from schools in Ibadan Metropolis in Nigeria, Ozean Journal of Social Science, 4(3), 163-175.

Rivkin, S. G., Hanushek, E. A., \& Kain, J. F. (2005). Teachers, schools and academic achievement. Econometric, 73, 417-458.

Salman, M. F. (2002). Relevance of mathematics at tertiary level of education to national development. Sokoto Education Review, 128-137.

Salman, M. F., \& Adeniyi, C. O. (2012). Influence of teacher's qualification and experience on secondary school students Performance in mathematics. J of Math Assoc of Nigeria, 37, 134-141.

Seah, W. T. (2007). Qualities co-valued in effective Mathematics lesson in Australia: Preliminary findings. Proceedings of the 31st conference of the international group for the psychology of Mathematics Education, 4,161-168. Seoul: PME.

Stanford, B. H. (2001). Reflections of resilient: Persevering urban teachers. Teachers Education Quarterly, 28, 75-87.

Tuncay, S., \& Omur, A. (2009). Identifying factors affecting the mathematics achievement of students for better instructional design. Retrieved from http://www.itdl.org/index.htm

Uche, S. A. (2011). The multiple intelligence teaching method and mathematics teaching. Journal of Research in National Development, (9)1.

Vandiver, B. (2011). The impact of school facilities on learning enrolment (Unpublished doctoral dissertation). Capella University.

Wenglinsky, H. (2000). Teaching the teachers: Different settings, different results. Princeton, NJ: Educational Testing Service.

West African Examination Council (2010-2016). Mathematics chief examiner report on may/june school certificate examination. Lagos.

Zachariah, K. M., Komen, K., George, M. M., \& George, R. N. (2012). Factor contributing to students' poor performance in mathematics at Kenya certificate of secondary education in Kenya. American International Journal of Contemporary Research, 2, 87-91. 